\title{
Water Disputes over Inter - State Rivers: The Indian Experience
}

Sharad S Javali*

\section{Introduction}

Water is the most important natural resource; it is essential to all forms of life. Surface water and ground water are the two forms of water resource. India is sustained by agricultural economy. It leads the world in the irrigation sector. The irrigation facilities have been the central feature of India's agricultural development since independence. There has been a huge investment in the irrigation sector during the last six decades. Yet, there is a need for further extension of irrigation facilities to step up the production of food. River projects are being designed so as to provide for hydroelectric power, flood control, navigation, recreation facilities and fish culture. Their uses would also include domestic (meaning drinking water with high priority) and industrial uses. All these uses of water contribute to the improvement of the country's general standard of living. ${ }^{1}$

The first commission appointed in India for the adjudication of a water dispute, headed by Justice B.N. Rau, had held that under the scheme of the Government of India Act, 1935, a province could not claim to do whatever it liked with the water of a river, dispensing

\footnotetext{
* Senior Advocate, Supreme Court of India; sharadjavali@usa.net. This is the edited version of the lecture delivered at School of Law, Christ University, Bengaluru at the Faulty Development Program on March 21, 2015.

${ }^{1}$ MisRa S.D., INDiA- THE LAND AND PEOPle: Rivers Of INDiA 140-41 (New Delhi National Book Trust, India, illustrated ed. 1970).
} 
with the injury which such a use might have on lower riparian provinces or states.

The Supreme Court of India has recognized that the right to the use of flowing water is publici juris and common to all the riparian proprietors. However, it is not an absolute and exclusive right to all the water flowing past their land, so that any obstruction would give rise to a cause of action but it is a right to the flow and enjoyment of the water, subject to a similar right vested in all the proprietors to the reasonable enjoyment of the same gift of providence. ${ }^{2}$ (The Court in President's Reference in Re: Cauvery Waters Disputes Tribunal observed:

Though the waters of an Inter-State river pass through the territories of the riparian States such waters cannot be said to be located in any one State, they are in a state of flow, and no State can claim exclusive ownership of such waters.

Over three decades ago, Minister K.L. Rao speaking for the central government proposed the linking of the rivers Ganga and the Cauvery. In the 1990s, the central government appointed a commission to examine the strategy for water resource development. The commission, ${ }^{3}$ while supporting the proposal, suggested an examination of the relevant aspects as also the idea of link canals to direct waters from surplus basins to water short basins. The Supreme Court also speaking in a Public Interest Litigation proceeding directed the central government to draw up and implement a programme to interlink major rivers.

\section{Inter-State Water Disputes: Historical Perspective}

\section{Government of India Acts of 1919 and 1935}

There were developments in the North of India, referable to the then constitutional documents. They related to the states of Punjab and Sind (the then part of the Bombay Presidency). There were

\footnotetext{
${ }^{2}$ Kansas v. Colorado, 206 U.S. 461906.

${ }^{3}$ Central Water Commission Guidelines for the 'Preparation of River Basin Master Plan'
} 
apprehensions about the availability of adequate water for the Bhakhra Project of Punjab and Sukkar Project in Sind.

The Government of India Act, 1919 was first of the constitutional documents, providing inter alia for the resolution of water disputes. The Government of India was competent to decide all inter-state river matters and disputes by an executive order.

The central government invoking its powers under the Government of India Act, 1919 appointed a committee (known as the Anderson Committee) comprising experts to investigate the disputes and apprehensions surrounding inter-state water disputes. The Anderson Committee was able to secure full agreement from all parties and the Government of India approved its unanimous recommendations in the year 1937.

Meanwhile, with the coming into force of the Government of India Act 1935, on April 1, 1937, the development of river waters became a purely provincial subject. The Governor General could intervene only when a complaint was lodged by one province against another. The Government of India could not, therefore, act on the basis of the report of the Anderson Committee constituted under the 1919 Act. It became necessary to refer the dispute under the 1935 Act.

The procedure under the Government of India Act, 1935 involved the appointment of a Commission by the Governor General in response to the complaint by a province to investigate matters. ${ }^{4}$

Upon submission of the report by the commission, Section 131(3) empowered the Governor General to seek an explanation or guidance by reference to the report. The matter could be referred again to the commission for further investigation and report.

Governor General was further empowered by Section 131(5) to render a decision or order upon the report of the commission as he could deem proper. The proviso required the Governor General to refer the matter to His Majesty in Council if required, by any of the provinces and thereupon the decision of His Majesty in Council would be given effect to by the provinces.

${ }^{4}$ The Government of India Act, 1935, § 130 to 134. 
Accordingly, the Governor General appointed the Indus Commission headed by Justice B.N. Rau of the Calcutta High Court in September 1941 on a complaint by the Sind Province. This was the first commission appointed in India for the adjudication of a water dispute within the scope of the Government of India Act, 1935.

In dealing with Sind's complaints and Punjab's defenses, the commission discussed at great length, the rights on flowing waters and the law in India concerning the same, between individual riparian owners, governments of different provinces, the government of a province and inhabitants of that province concerned.

The Indus Commission rejected both the doctrine of absolute sovereignty and the doctrine of riparian rights while dealing with the rights of different provinces with respect to the waters of Indus and its tributaries. It summarised its decision on preliminary issues as follows ${ }^{5}$

The rights of the several units concerned in this dispute must be determined by applying neither the doctrine of sovereignty, nor the doctrine of riparian rights, but the rule of 'equitable apportionment'each unit being entitled to a fair share of the waters of the Indus and its tributaries.

While arriving at this finding, the Indus Commission referred to some of the leading English cases such as Embrey v. Owen6; Swindon Waterworks Co. v. Wilts and Berks Canal Navigation Co.7; McCartney v. Londonderry and Lough Swilly Ry. Co. ${ }^{8}$, and Secretary of State v. S. Subbarayudu. ${ }^{9}$

\footnotetext{
${ }^{5}$ Report of the Indus Commission, Vol. 1, 13 (Government of India Press, Shimla, 1942).

${ }^{6}(1851) 6$ Ex. 353.

7 (1875) L. R. 7 H. L. 697.

8 [1904] A.C. 301.

${ }^{9}$ AIR 1932 PC 46; (1931) 59 I.A. 56.
} 
The report of the Indus Commission was based on considerations of equitable apportionment as enunciated in the decision of the United States Supreme Court. It was the first authoritative pronouncement on inter se rights of states in flowing waters or in waters of an inter-state river.

The commission observed:

A third principle that has been advocated is that of "equitable apportionment", that is to say, that every riparian State is entitled to a fair share of the waters of an Inter-State river. What is a fair share must depend on the circumstances of each case; but the river is for the common benefit of the whole community through whose territories it flows, even though those territories may be divided by political frontiers.

It referred to various American and European precedents in favour of the rule of equitable apportionment.

Thereafter, the commission dealt with the class of cases and the law in India as between the government of one province and the government or inhabitants of another province, insofar as rights in the flowing water of a river were concerned. The commission after examining the provisions of Entry 19 of List II as also Sections 49 (2) and 130 to 132 of the Government of India Act, 1935, held that ${ }^{10}$

The Act therefore recognizes the principle that no Province can be given an entirely free hand in respect of a common source of water such as an inter-provincial river. This is in accordance with the trend of international law as well as of the law administered in all federations with respect to the rights of different States in an Inter-State river.

The report of the Rau Commission submitted in July 1942 was not accepted by Punjab and Sind. Both the governments represented against the findings and the recommendations of the commission

10 Supra note 5 at 21. 
to the Government of India, under Section 131 of the Government of India Act, 1935. The matter was referred by the Governor General to His Majesty and Council. Even though mutual consultations led to a draft agreement prepared in September 1945, nothing materialized finally till August 15, 1947. The attempted settlement proved abortive.

Thus the work of the commission under the 1935 Act did not become effective. The partition of the country and events thereafter, led to the Indus Treaty between India and Pakistan in 1960.

\section{The Cauvery Dispute}

The developments in the Cauvery River Water Dispute depict the historical developments spread over a period of 150 years. It will be useful to convey a brief outline.

The first of the constitutional documents was the Government of India Act, 1858. The Government of Madras was directly administered by His Majesty, the Crown of England through the office of the Secretary of State in Council at London. Madras enjoyed its patronage. The Princely State of Mysore under its Maharaja was subject to the suzerainty of the British Crown.

The Cauvery originates in Coorg, now in the State of Karnataka. It runs a length of $802 \mathrm{~km}$, till the Bay of Bengal. In Karnataka, its length is $381 \mathrm{~km}$. In Tamil Nadu it extends to $357 \mathrm{~km}$. The total yield of water is now determined to be 740 tmc (A tmc means, a thousand Million Cubic Feet, good enough to irrigate 6000 acres of rice cultivation or 15,000 acres of dry crops) Karnataka's contribution therein is $392 \mathrm{tmc}$ of water. Tamil Nadu and Pondicherry together contribute 222 tmc of water. Karnataka's drought area is over $21,817 \mathrm{sq}$. $\mathrm{kms}$, to the extent of $63 \%$. However, Karnataka has been denied its share because of historical reasons. A major portion of the water is claimed by Tamil Nadu, on the basis of prior appropriation or the first appropriation of water from a stream. Mostly lower riparians have the first chance to draw water in deltaic regions due to reasons of geography and quality of soil in the delta area, which inevitably supports agricultural operations. 
Upto the nineteenth century, irrigation was based on the course of the river. The water flowing from the river Cauvery along with the water supplied by tributaries, were sufficient to irrigate the lands under cultivation in the erstwhile states of Mysore and Madras. However, with an extension of cultivation areas by the aforesaid two states, disputes relating to the sharing of the waters of the Cauvery, arose and took a serious turn. Madras took up the matter with the Government of India. ${ }^{11}$

The British Government involved the princely state of Mysore in a series of developments in the name of negotiations. In 1892, rules were drawn by the British Government known as 'Rules Defining the Limits within which No New Irrigation Works are to be Constructed by the Mysore State Without Previous Reference to the Madras Government'. It was described as an agreement between the then British province of Madras and the princely state of Mysore. In view of this agreement, the government of Mysore required the prior consent from the government of Madras in respect of any construction proposed to be made, including any new irrigation reservoirs across the rivers named therein.

The princely state of Mysore approached the then British Province of Madras for permission to construct a dam near Mysore, since then known as the Krishna Raja Sagara Dam (KRS). The province of Madras did not grant its consent. Several meetings were held between the two States. Sir M. Visweswarayya represented Mysore between 1901-1910. This led to the reference of the dispute to arbitration in 1913. The award rendered by the Arbitrator in 1914 was accepted by Mysore. The province of Madras appealed unsuccessfully to the Governor General in India and later approached the Secretary of State in London. The role played by the Secretary of State effectively frustrated the award. The government of Mysore was compelled to be involved in protracted negotiations for the next decade. ${ }^{12}$ An agreement was brought about in 1924 based on reciprocity that Madras would have a dam at Mettur, twice the size of the KRS in Mysore.

${ }^{11}$ Cauvery Water Disputes Tribunal Report, Vol. 2, Chap. I, 1 (2007).

12 Id. at 7. 
These agreements effectively denied the scope for irrigation in Mysore beyond the KRS project. The stipulations of the agreement and the rules of regulation required substantial flows of the Cauvery to downwards for the benefit of the delta area in the state of Madras. Mysore could hold a small quantity of $45 \mathrm{tmc}$ at the KRS Dam but only after the release of the required water due to Madras.

The India Independence Act, 1947 enacted by the British Parliament provided for the lapse of agreements entered between the princely states. Further developments took place subsequently including the merger of princely states, the promulgation of the Constitution of India in 1950, the reorganization of states in 1956 and the formation of a new state now known as Karnataka. The agreements of 1892 and 1924 were not ratified by the new state of Mysore (now Karnataka).

The Constitution of India commenced its operation in 1950. Article 131 provided for the original jurisdiction of the Supreme Court in any dispute inter alia between two or more states or between the government of India and one or more states. Article 262 provided for a parliamentary legislation for the adjudication of disputes between states with respect to water and water supplies. It also empowered the Parliament to enact a law for the exclusion of jurisdiction of the Supreme Court. Parliament enacted the InterState Water Disputes Act in 1956 in both respects.

The state of Mysore (now Karnataka) contended stating that the agreements were not valid and enforceable, but was arbitrary and unjust, more so after the commencement of Constitution in 1950. The clause concerning 'limit flows' contemplated the release of water by Mysore from KRS to be far in excess of the true requirements of Madras (now Tamil Nadu).

Disputes arose and negotiations (as required by statute) were initiated between Karnataka and Tamil Nadu, inter alia at the instance of the central government. Karnataka highlighted that it was prejudicially affected by the excessive use of the Cauvery waters by Tamil Nadu. The basin states including the States of Karnataka and Tamil Nadu concurred that any attempt to review the agreement should be discontinued and a wholesome approach 
to solve the problem should instead be adopted. Yet a solution could not be negotiated and agreed upon.

A reference dated 02-06-1990 was made by the central government under the Inter State Water Disputes Act, 1956 to a tribunal set up for the adjudication of the Cauvery Water Dispute, based on a complaint submitted by the State of Tamil Nadu under the Act, for implementation of the pre-constitutional Agreements of 1892 and 1924.

The tribunal after protracted proceedings has held at this distance of time that the Agreements are valid. The main findings of the tribunal may be stated as follows:

a. The total yield (surface flows) in the Cauvery basin at $50 \%$ dependability is about $740 \mathrm{tmc}$ and at $75 \%$ dependability is about 670 tmc. $^{13}$

b. The terms of the agreements of 1892 and 1924 have to be kept in view while considering the developments in different states vis-a-vis the share of the riparian states. ${ }^{14}$

c. Article 363 of the Constitution prescribing a bar on interference by the courts, in disputes arising out of certain treaties, agreements etc, with any erstwhile ruler of an Indian state executed before the commencement of the Constitution, does not prevent an inquiry by the tribunal, having exclusive jurisdiction under the Constitution, to examine a dispute in respect of the use, distribution, or control of waters of any inter-state river or river valley.

d. Considering the severe limitations in the assessment of ground water resource, the tribunal assumed the available ground water to an extent of $20 \mathrm{tmc}$ to be used by Tamil Nadu conjunctively with surface water in the Cauvery Delta region. ${ }^{15}$

${ }^{13}$ Cauvery Water Disputes Tribunal Report, Vol. 3, Chap. I, 74 (2007).

${ }^{14}$ Cauvery Water Disputes Tribunal Report, Vol. 2, Chap. 2, 77 (2007).

${ }^{15}$ Cauvery Water Disputes Tribunal Report, Vol. 3, Chap. 3, 173 (2007). 
e. The area considered reasonable for Tamil Nadu to the extent of 2470 thousand acres. ${ }^{16}$

f. Areas considered reasonable for Karnataka is of the order of 1885 thousand acres. ${ }^{17}$

g. The tribunal denied drinking water to Bengaluru city stating: Since two thirds of Bengaluru city lies outside the basin, we are considering the drinking water requirement of Bengaluru city for its portion of areas which lies within the Cauvery basin along with remaining basin area...... ${ }^{18}$

h. The total requirement of Tamil Nadu is determined as $390.85 \mathrm{tmc}$ for 24.71 lakh acres including $10 \mathrm{tmc}$ for reservoir losses ${ }^{19}$.

i. The total water requirement of Karnataka for providing irrigation to 18. 85 lakh acres, is determined as $250.62 \mathrm{tmc}$ including the water used for minor irrigation and evaporation losses..$^{20}$ The Tribunal has denied water to an extent of 2.10 lakh acres of ayacut and 6.5 lakh acres of cropped area in Karnataka under its committed projects on which huge investment of Rs 4,500 crores has been made over the years.

j. The final shares allocated to the basin States are:

Kerala

Karnataka

Tamil Nadu

Pondicherry
$30 \mathrm{Tmc}$

$270 \mathrm{Tmc}$

419 Tmc

$7 \mathrm{Tmc}$

Provisions for environmental protection of $10 \mathrm{tmc}$ and inevitable escapages of $4 \mathrm{tmc}$, accounted for the total quantity of $740 \mathrm{tmc}^{21}$.

\footnotetext{
16 Cauvery Water Disputes Tribunal Report, Vol. 4, Chap. 2, 111 (2007).

17 Cauvery Water Disputes Tribunal Report, Vol. 4, Chap. 3, 172 (2007).

18 Cauvery Water Disputes Tribunal Report, Vol. 5, Chap. 4, 102 (2007).

19 Cauvery Water Disputes Tribunal Report, Vol. 5, Chap. 3, 86 (2007).

20 Id. at 94.

21 Cauvery Water Disputes Tribunal Report, Vol. 5, Chap. 7, 202 (2007).
} 
Tamil Nadu has been allocated $57 \%$ of water, and Karnataka has been allocated $36.5 \%$, though Karnataka has large drought areas including the areas in the Kabini and Harangi sub-basins and contributes the bulk of water to the basin. Invoking Article 136 of the Constitution, appeals by special leave are now pending before the Supreme Court of India, from the decision of the Cauvery Tribunal.

\section{Post 1950 Water Disputes Tribunals and Machinery for Adjudication of Water Disputes: Supreme Court's Jurisdiction and its Exclusion}

It is realized that water dispute involves the politico-legal approach towards a solution. 'Disputes over river waters have been known for their sensitive and explosive nature' said the legendary N.D. Gulhati who steered India in achieving the Indus treaty.

The Government of India Act, 1935 was replaced after independence, by the promulgation of the Constitution of India in 1950. A dispute between the states of the Indian Union concerning any matter, including a dispute relating to waters of an Inter-State river, was subject to the jurisdiction of Article 131 of the Constitution:

The only course then open to was to institute a suit in the Supreme Court under its original jurisdiction. Any decision rendered by the Court would have been a final decision binding on the parties and the law declared by it would be binding on all courts within the territory of India under Article 141. Further, it would have been a decision without any scope for an appeal.

The exclusion of jurisdiction clause contained in Section 133 of the Government of India Act, 1935 has been embodied in Article 262 (2) of the Constitution of India. The mechanism for adjudication of disputes and complaints in respect of water and water supplies has been separately provided by a legislation to be enacted under Article 262 (1) of the Constitution of India.

None other than the honourable Dr. B.R. Ambedkar in the Constituent Assembly, introduced Article 242A (corresponding to 
the present Article 262) and stated the reasons. An extract from the debates is reproduced:

Sir, originally this article provided for Presidential action. It was thought that these disputes regarding water and so on may be very rare, and consequently they may be disposed of by some kind of special machinery that might be appointed. But in view of the fact that we are now creating various corporations and these corporations will be endowed with power of taking possession of property and other things, very many disputes may arise and consequently it would be necessary to appoint one permanent body to deal with these questions. Consequently it has been felt that the original draft or proposal was too hide-bound or too stereo-typed to allow any elastic action that may be necessary to be taken for meeting with these problems. Consequently, I am now proposing this new article which leaves it to Parliament to make laws for the settlement of these disputes.

Article 262 was not invoked till 1956, to legislate for the adjudication of disputes between states concerning waters of interstate rivers. The Supreme Court of India has affirmed that the Inter-State Water Disputes Act has been enacted under Article 262 and not by reference to Entry 56 of List I or Entry 17 of List II in the Seventh Schedule and none of the entries in the Seventh Schedule mention the topic of adjudication of disputes relating to inter-state river waters. Article 262 specifically provides for such adjudication. 22 It is reproduced herein below:

262. Adjudication of disputes relating to waters of Inter-State rivers/or river valleys:

1) Parliament may by law provide for the adjudication of any dispute or complaint with respect to the use, distribution or control of the waters of, or in, any Inter-State river or river valley.

22 In re. Cauvery, 1993 Supp. (1) S.C.C. 134. 
2) Notwithstanding anything in this Constitution, Parliament may by law provide that neither the Supreme Court nor any other court shall exercise jurisdiction in respect of any such dispute or complaint as is referred to in Clause (1).

In pursuance of this power, the Parliament enacted the Inter-State Water Disputes Act in 1956, six years after the commencement of the Constitution. The Act contains provisions similar to Section 130, 131 and132 of the Government of India Act of 1935. Sections 3, 4, 5, 6 and 11 may be reproduced for the present purpose:

Section 3 - If it appears to the Government of any State that a water dispute with the Government of another State has arisen or is likely to arise by reason of the fact that the interests of the State, or of any of the inhabitance thereof, in the waters of an InterState river or river valley have been, or are likely to be, affected prejudicially by

a. any executive action or legislation taken or passed, or proposed to be taken or passed, by the other State or

b. the failure of the other State or any authority therein to exercise any of their powers with respect to the use, distribution or control of such waters; or

c. the failure of the other State to implement the terms of any agreement relating to the use, distribution or control of such waters; the State Government may, in such form and manner as may be prescribed, request the Central Government to refer the water dispute to a Tribunal for adjudication.

Section 4 - (1) When any request under section 3 is received from any State Government in respect of any water dispute and the Central Government is of opinion that the water dispute cannot be settled by negotiations, the Central Government shall, within a 
period not exceeding one year from the date of receipt of such request, by notification in the Official Gazette, constitute a Water Disputes Tribunal for the adjudication of the water dispute:

Provided that any dispute settled by a Tribunal before the commencement of Inter-State Water Disputes (Amendment) Act, 2002 shall not be reopened.

(2) The Tribunal shall consist of a Chairman and two other members nominated in this behalf by the Chief Justice of India from among persons who at the time of such nomination are Judges of the Supreme Court or of a High Court.

(3) The Central Government may, in consultation with the Tribunal, appoint two or more persons as assessors to advise the Tribunal in the proceedings before it.

Section 5 - (1) When a Tribunal has been constituted under section 4, the Central Government shall, subject to the prohibition contained in section 8 , refer the water dispute and any matter appearing to be connected with, or relevant to, the water dispute to the Tribunal for adjudication.

(2) The Tribunal shall investigate the matters referred to it and forward to the Central Government a report setting out the facts as found by it and giving its decision on the matters referred to it within a period of three years.

Provided that if the decision cannot be given for unavoidable reason, within a period of three years, the Central Government may extend the period for a further period not exceeding two years.

(3) If, upon consideration of the decision of the Tribunal, the Central Government or any State Government is of opinion that anything therein contained requires explanation or that guidance is 
needed upon any point not originally referred to the Tribunal, the Central Government or the State Government, as the case may be, within three months from the date of the decision, again refer the matter to the Tribunal for further consideration, and on such reference, the Tribunal may forward to the Central Government a further report within one year from the date of such reference giving such explanation or guidance as it deems fit and in such a case, the decision of the Tribunal shall be deemed to be modified accordingly:

Provided that the period of one year within which the Tribunal may forward its report to the Central Government may be extended by the Central Government, for such further period as it considers necessary.

Section 6 - (1) The Central Government shall publish the decision of the Tribunal in the Official Gazette and the decision shall be final and binding on the parties to the dispute and shall be given effect to by them.

(2) The decision of the Tribunal, after its publication in the Official Gazette by the Central Government under sub-section (1), shall have the same force as an order or decree of the Supreme Court.

Section 11 - Notwithstanding anything contained in any other law, neither the Supreme Court nor any other Court shall have or exercise jurisdiction in respect of any water dispute which may be referred to a Tribunal under the Act.

The Act has defined 'water dispute' as primarily for the use, distribution or control of the waters of, or in any inter-state river or river valley [Section2(c)]. In the event of a water dispute, if the government of a state is of the opinion that the interests of a state or of its inhabitants are likely to be prejudicially affected by the acts of another state or by the interpretation of or by the failure of the other state to implement the terms of any agreement relating to the 
use, distribution or control of such waters, it may file a complaint (as may be described in common parlance), requesting the central government to refer the water dispute to a tribunal for adjudication. The Act initially contemplated negotiations between the disputant states and its intervention only if the negotiations fail. Prejudicial affectation or injury to the interests of a state having any part of the basin of an inter-state river, within its territories is the foundation for initiating the procedure under the Act for reference of a water dispute for adjudication. Interests of a state are primarily referable to the basin area. They include irrigation, power generation, drinking water, ground water as also domestic and industrial uses. Priority is accorded to drinking water as also to the in-basin needs for other purposes.

The central government shall then constitute a tribunal consisting of a chairman and two other members nominated by the Chief Justice of India from among the sitting judges of the Supreme Court or of a high court. The tribunal is aided by assessors. It is, however, made clear that any dispute settled by a tribunal set up under the Act before 2002 shall not be reopened.

The adjudication process by a tribunal has been described as an 'investigation' of the matters referred to it. At the conclusion of its proceedings, the tribunal forwards its report setting out the facts as found by it and giving its decision on the matters referred to it. Subject to certain provisions of the Code of Civil Procedure, 1908 the tribunal has the power to regulate its practice and procedure.

The Inter-State Water Disputes Act, 1956 does not require the tribunal to conduct a trial as such. It is possible to understand from the object of the Act that its mandate is to investigate and to record the facts as found by it. The Act has also provided that the decision of the tribunal shall have the same force as an order or decree of the Supreme Court.

A tribunal may devise its own approach in deciding a water dispute. Different tribunals have adopted different ways; some of them, principally the Narmada, Cauvery and Krishna II tribunals have been guided by strict procedures of trial. They involved considerable amount of time in complying with the rules of evidence. The judgment is in the nature of a report and the 
decision is in the nature of a decree. The tribunals have provided a mechanism to implement their decisions.

There is however scope for the party states or for the central government to make a further reference seeking clarification or explanation concerning the decision of a tribunal. ${ }^{23}$ It is neither an appeal nor a petition for review.

The Inter-State Water Disputes Act, $1956{ }^{24}$ excludes the jurisdiction of the Supreme Court or of any other court in respect of any water dispute that may be referred to the tribunal. The Supreme Court of India has however laid down that it is one of its primary responsibilities to determine the jurisdiction, power and limits of any tribunal or authority created under a statute. While the court has no jurisdiction to decide the merits of the dispute referred for adjudication, to a tribunal, it observed, ${ }^{25}$ "The Supreme Court is the ultimate interpreter of the provisions of the Inter State Water Disputes Act, 1956"

It is debatable as to whether any appeal can be carried from the final adjudication and decision of the tribunal, to the Supreme Court. It is in this regard that the Supreme Court had occasion to give meaning to the provisions of the Act. It has stated that the original jurisdiction of the inter-state water dispute, which may be referred to a tribunal, is the subject of exclusion from the purview of any court including the Supreme Court. ${ }^{26}$ This observation has the potential to indirectly support an appeal and the appellate jurisdiction of the Supreme Court.

A piquant situation is discernible in the development of law in this behalf. The provisions of the Inter-State Water Disputes Act, 1956 do not provide for an appeal from the decision of a tribunal. There is also the specific provision (Section II) excluding the jurisdiction of the Supreme Court and of any other court in the matter of a water dispute (as defined under the Act). It may also be noted that states aggrieved by the decisions of different tribunals, have

23 The Inter-State Water Disputes Act, 1956, § 5(3).

24 The Inter-State Water Disputes Act, 1956, § 11.

${ }^{25}$ State of Tamil Nadu Etc. v. State of Karnataka, 1991 Supp. (1) S.C.C. 240.

${ }^{26}$ In re. Cauvery, 1993 Supp. (1) S.C.C. 96. 
invoked Article 136 of the Constitution of India and have approached the apex court seeking and obtaining special leave to appeal. The maintainability of such appeals, is based on the terms of Article 136 of the Constitution. It may be reproduced for the immediate understanding:

136. Special leave to appeal by the Supreme Court - (1) Notwithstanding anything in this Chapter, the Supreme Court may, in its discretion, grant special leave to appeal from any judgment, decree, determination, sentence or order in any cause or matter passed or made by any court or tribunal in the territory of India.

The contention is that it is open to the Supreme Court in its discretion, to grant special leave to appeal from any judgment, decree, determination or order in any cause or matter as may be passed or made by any court or tribunal.

Articles 131 and 136 prescribe the jurisdiction of Supreme Court, original and appellate, in all matters. They may be read with the specific provisions of Article 262 and the provisions of the InterState Water Disputes Act, 1956 enacted in accordance therewith, specifically excluding the jurisdiction of the Supreme Court. A water disputes tribunal is constituted under the special law, comprising sitting judges of the Supreme Court or of the high courts. Most other tribunals are composed of retired Judges, bureaucrats or persons specialized in different subjects. The question as to whether the awards from both the categories be equated and treated alike in invoking Article 136 of the Constitution and appeals may be entertained by the Supreme Court can be answered in the affirmative. The maintainability of appeals, has been upheld from orders and judgments of various tribunals such as the Administrative Tribunals, Income Tax Appellate Tribunal, National Consumers Disputes Redressal Commission and the like.

Questions of construction of Articles 131, 136 and 262 of the Constitution may have to be considered:

a. Had no law been made by recourse to Article 262, the States would have had the only option of moving the Supreme 
Court by means of a suit under Article 131. In that event, there would have been no scope for appeal from an order of the Supreme Court.

b. The Inter-State Water Disputes Act, 1956 provides for the exclusion of jurisdiction of the Supreme Court (in terms of Article 262). A tribunal composed of sitting Judges may be set up for investigating facts and adjudicating water disputes between States aided by assessors. The Act has provided that the decision of such a tribunal shall have the force of a decree of the Supreme Court.

The ascertainment of objects of the Constituent Assembly in providing for dissimilar provisions in Articles 131 and 262 or that of Parliament in enacting the Inter-State Water Disputes Act in 1956, come in for consideration. Is there a clear message whether they intended the Supreme Court to decide a water dispute or they did not? According to one view, if it is the intention of the Act of 1956 to exclude the jurisdiction of the Supreme Court, should the Court entertain appeals from the decisions of water disputes tribunals by grant of Special Leave under Article 136?

c. The other view is that the exclusion of jurisdiction of the Supreme Court is limited to the original cognizance as conferred on a tribunal under the Inter-State Water Disputes Act, 1956 and that appeals by special leave under Article 136 being an appellate procedure, would not be part of the provisions for exclusion of jurisdiction under the Act; such appeals would be permissible and maintainable.

d. The upshot of these references is whether the enactment of the Inter-State Water Disputes Act, 1956 and the adjudication of a water dispute by a tribunal, are intended to provide scope for an appeal to the same apex court from the decision of a high powered tribunal, such as the InterState Water Disputes Tribunal, irrespective of the consequences of the extended time factor in resolving disputes? Considerations of interests of a developing country like India may have to be taken into account. 
The experience undergone by the States and the Union Government would naturally give rise to a thought process to review the provisions of the Constitution of India concerning the control and use of inter-state river waters and those of the InterState Water Disputes Act, 1956 in order to find out whether they have promoted the resolution of disputes satisfactorily in national interests. The decisions rendered by most of the tribunals have not attained finality. They are pending determination before the Supreme Court of India. Could there have been scope for a different approach in making laws for the purpose by avoiding/which avoids long drawn discords and litigations between States? Whether the intellectuals, professors, jurists and scholars of law of the country can respond and recommend the need for a course of action to promote continued progress of a developing country like India, without avoidable obstructions?

\section{United States Supreme Court on Inter-State Water Disputes}

The Indus Commission first and the Supreme Court of India 50 years later, have adopted the law of 'equitable utilisation' developed by the United States Supreme Court in deciding water disputes between States involving the apportionment of waters of inter- state rivers. The Supreme Court of India ${ }^{27}$ has approved the law stated by the U.S. Supreme Court in the State of Kansas v. State of Colorado28:

One cardinal rule, underlying all the relations of the States to each other, is that of equality of right. Each State stands on the same level with all the rest. It can impose its own legislation on no one of the others and is bound to yield its own view to none....the action of one State reaches, through the agency of natural laws into the territory of another State, the question of the extent and the limitation of the rights of the two States becomes a matter of justiciable dispute between them...this court is called upon to settle that dispute in such a way as will recognise the

\footnotetext{
${ }^{27}$ In re Cauvery, 1993 Supp (1) S.C.C. 138.

28206 U.S. 461906.
} 
equal rights of both and at the same time establish justice between them.

The U.S. Constitution makes no mention of water. But the document, whichcame into effect in 1789, addresses the role of the federal government and States, and expressly grants powers to Congress to regulate interstate commerce. As early as the 1800 s, the U.S. Supreme Court held that interstate commerce included shipping and navigation. In more recent times, the U.S. Supreme Court has held that water sold across State lines implicates the interstate commerce clause; states may therefore not impose unreasonable bans or restrictions on the movement of interstate water.

Congress may apportion waters in an interstate river by statute, though it has done so only twice in the U.S. history. The complexity of most water allocation schemes, the competing state interests and the sheer amount of time needed to understand the technical issues have deterred Congress from allocating interstate waters by itself.

The U.S. Constitution allows states to sue each other in the Supreme Court, which has original jurisdiction for cases involving equitable apportionment of waters of inter-state rivers among the contesting States. When a State files a petition under this provision of the Constitution, the case goes directly to the Supreme Court, which appoints a special master (who is an independent fact finder) to take evidence and make preliminary rulings. If the issue indicates towards being an interstate water dispute, the special master conducts hearings and proposes an equitable apportionment of the river. This process has even taken years with respect to some rivers. The Supreme Court can then approve, reject or modify the special master's findings. States are understandably reluctant to go through this time consuming and uncertain process, which perhaps explains why the list of Supreme Court water apportionment cases is short and limited to only eight rivers.

The states themselves may solve their water disputes by signing a 'compact' with each other, subject to approval by the Congress. A compact is a contract and is a binding legal document that has the force of law. The authority for states to sign these agreements is derived from the 'compact clause' of the U.S. Constitution. 
Compacts between two or more states now address diverse subjects such as child custody, bridge tolls, nuclear waste, taxes and water. The first compact that apportioned interstate waters was signed in 1925. It divided the waters of a small river, the La Plata River between the States of Colorado and New Mexico. The most recent interstate water apportionment compact was executed in $1980 .{ }^{29}$

\section{Helsinki Rules ${ }^{30}$}

The International Law Association (ILA), a body comprising various countries as its members, has conducted periodical conferences to deliberate inter alia on the formulation of rules which govern the use of waters of international rivers or drainage basins. The statements and resolutions adopted by the ILA in first 10 years since it began its work on international rivers, paved the way for a set of comprehensive rules evolved by the ILA at its meeting held in Helsinki in 1966. Those rules are known as the 'Helsinki Rules on the Uses of the Waters of International Rivers'. A drainage basin is defined as "a geographical area extending over two or more states determined by the watershed limits of the system of waters, including surface and underground waters, flowing into a common terminus". The Helsinki Rules established the principle of 'reasonable and equitable utilization' of the waters of an international drainage basin among the riparian states as the basic principle of international water law and supported the principle of 'existing use'. The Helsinki Rules covering a wide range of issues have specified a number of factors for determining the same reasonable and equitable share for each basin state. The relevant articles of the Rules are as follows:-

29 Daniel Seligman, Resolving Interstate Water Conflicts: A Comparison of the Way India and the United States Address Disputes on Interstate Rivers, 21 (Working Paper series Serial No. IWP/WP/No.2/2011), available at www.lkyspp.nus.edu.sg/iwp.

30 Salman M.A. Salman, The Helsinki Rules, the UN Watercourses Convention and the Berlin Rules: Perspective on International Water Law, 43(4) WATER RESOURCE DEVELOPMENT 625-640(2007). 


\section{Article V}

I. What is a reasonable and equitable share within the meaning of Article IV is to be determined in the light of all the relevant factors in each particular case.

II. Relevant factors which are to be considered include, but are not limited to:

1. geography of the basin, including, in particular, the extent of the drainage area in the territory of each basin State;

2. The hydrology of the basin, including, in particular, the contribution of water by each basin State;

3. The climate affecting the basin;

4. The past utilization of the waters of the basin, including, in particular, existing utilization;

5. The economic and social needs of each basin State;

6. The population dependent on the waters of the basin in each basin State;

7. The comparative costs of alternative means of satisfying the economic and social needs of each basin State;

8. The availability of other resources;

9. The avoidance of unnecessary waste in the utilization of waters of the basin;

10. The practicability of compensation to one or more of the co-basin States as a means of adjusting conflicts among uses; and

11. The degree to which the needs of a basin State may be satisfied, without causing substantial injury to a co-basin State. 
III. The weight to be given to each factor is to be determined by its importance in comparison with that of other relevant factors. In determining what is reasonable and equitable share, all relevant factors are to be considered together and a conclusion reached on the basis of the whole.

\section{Article VIII}

1. An existing reasonable use may continue in operation unless the factors justifying its continuance are outweighed by other factors leading to the conclusion that it be modified or terminated so as to accommodate a competing incompatible use.

a. A use that is in fact operational is deemed to have been an existing use from the time of the initiation of construction directly related to the use or, where such construction is not required, the undertaking of comparable acts of actual implementation.

b. Such a use continues to be an existing use until such time as it is discontinued with the intention that it be abandoned.

2. A use will not be deemed an existing use if at the time of becoming operational it is incompatible with an already existing reasonable use.

Forty years after the formulation of the Helsinki Rules, an attempt was made to revise them, at the conference of the ILA at Berlin, known as the Berlin Rules, 2004. ${ }^{31}$ They set forth a clear, cogent, and coherent summary of the relevant customary international law,

31 Joseph W. Dellapenna, The Berlin Rules on Water Resources: A New Paradigm for International Water Law, available at https:/ / www.google.co.in/ url?sa=t\&rct=j\&q=\&esrc=s\&source=web\&cd= $1 \&$ cad $=$ rja\&uact $=8 \&$ ved $=0 \mathrm{CB} 8 \mathrm{QFjAA} \& u r l=$ http $\% 3 \mathrm{~A} \% 2 \mathrm{~F} \% 2 \mathrm{Fwww}$.iwra.o rg\%2Fcongress $\% 2$ F2008\%2Fresource $\% 2$ Fauthors $\% 2 F a b s 568$ article.doc\&e i=WR0uVeGlOIKwuATzk4LQBg\&usg=AFQjCNFtVPqWV-o_zqUux5S95I1qxGXWA. 
incorporating the experience since the Helsinki Rules were adopted, taking into account the development of important bodies of complementary customary international law (including international environmental law, international human rights law, and the humanitarian law relating to the war and armed conflict), as well as the adoption by the General Assembly of the UN Convention. The major changes in the Berlin Rules relate to the rules of customary international law applicable to all waters, national as well as international, although there are certain refinements in the rules relating strictly to international waters. By including all of these matters within a single set of rules, a lawyer, a jurist, a water manager, a water policy maker, or anyone else concerned with the rules of customary international law pertaining to water, will find for the first time all the relevant law in one place.

In sum, the International Law Association approved of a new paradigm for the synthesizing of these rules into a coherent whole based on recognized legal principles. This new paradigm includes five general principles that apply to states in the management of all waters, wholly national or domestic waters as well as internationally shared waters:

1. Participatory water management;

2. Conjunctive management;

3. Integrated management;

4. Sustainability; and

5. Minimization of environmental harm.

The Berlin Rules also posit four further principles relating to water in a strictly international or transboundary context:

1. Cooperation;

2. Equitable utilization;

3. Avoidance of transboundary harm; and

4. Equitable participation.

This new paradigm, a coherent and comprehensive vision of the current state of relevant customary international law, should serve lawyers, water managements, and other decision makers well. 
Jerome Lipper of the New York Bar and member of the International Law Association, explained the basic legal concepts and the principle of equitable utilization, in the international context. Even as States continue to quarrel over their rights in international rivers on the basis of limited sovereignty, some authorities have already carried their thinking a step further and are concerning themselves with what has been termed the 'community' approach to international waters.

This approach seems from the practical consideration that the geography of a river often has little if any relationship to the political frontiers, which divide it, and in order to make optimum use of its waters, it is often necessary to develop an integrated program for the entire drainage basin. ${ }^{32}$

\section{Application of the Principle of Equitable Apportionment in India}

In India, the principle of equitable apportionment is in respect of inter-state rivers or river valleys. The waters of a river are for the common benefit of the country as a whole and not necessarily restricted to the inhabitants through whose territories it flows. The territories of the states are political boundaries, which can be changed at any time under Articles 2 and 3 of the Constitution of India. Therefore, the right to a share in the waters of any inter-state river of any state should not be dependent on whether the river actually flows through that state at a particular point of time or not, but whether in national interest, that political entity is entitled to a share in the waters of an inter-state river for use within its territories.

On what basis does the tribunal investigate in order to assess the facts? On what basis does a tribunal form its decision on the facts found by it? Tribunals have considered the river basin to be a unit and water use is primarily intended for the basin area. Priority is given for such uses, though diversion for out-basin uses is not illegal. The use of water is dictated by the nature of needs and the lack of alternative resources. Drought areas anywhere would have

32 Garretson, A. H. et al., The LAW OF InTERnAtional Drainage Basins 38 (New York: The Institute of International Law New York University School of Law Oceana Publications, Inc., 1967). 
priority, so does drinking water and non-consumptive use for power generation or industrial purpose.

It is imperative to have access to continued exchange of data and information concerning the river flows and the areas of needs in the territories of the basin States. The central government has the responsibility of controlling and regulating the use of water resources for the industry, irrigation, agriculture and power. It has the merit of having all the equipment, infrastructure and personnel competent for the purpose. It plays a crucial role in resolving water disputes and in promoting national interests.

a. The Ministries of Water Resources, Power, Industry, Agriculture and Environment, form part of the Central Government. They have the scope to provide relevant inputs beneficial for the adjudication and resolution of water disputes.

b. The government has periodically drawn up the National Water Policy in consultation with the States having due regard to the national interests.

c. All irrigation projects and power projects proposed by States, need the approval of the central government authorities, such as the Central Water Commission, and/ or by the Central Electricity Authority.

d. Under the Inter-State Water Disputes Act, the adjudicatory procedure is preceded by negotiations between the disputant States, which is regulated by the Central Government. If the negotiations fail, the Act has provided for the Central Government to refer the dispute for adjudication to a tribunal constituted by it. After the decision of the tribunal, the Act provides for the Central Government to make a further reference under Section 5(3) seeking clarifications and explanations, if any. The machineries for implementation of decisions of 
tribunals, have also assigned to the Central Government, significant role of control and regulation.

\section{Growth of Inter-State Water Tribunals in India}

The first tribunal under the Inter-State Water Disputes Act, 1956 was set up in 1969. The dispute was between the states of Maharashtra, Karnataka and the then state of Andhra Pradesh and could not be resolved by negotiations. The lowest riparian state of Andhra Pradesh had been utilizing the waters of Krishna river flowing mainly in the Delta Region, far in excess of the uses made by the upper riparian states of Maharashtra and Karnataka. The complaints of the Krishna basin states were referred by the central government for adjudication by the Krishna Water Disputes Tribunal. It was headed by Justice R.S. Bachawat, a retired judge of the Supreme Court of India.

The tribunal (Bachawat Tribunal) adopted as a measure the flow of $75 \%$ dependability, meaning the quantity of water available during $75 \%$ of the year. The extent of dependable flow is the magnitude of river flow, which may be expected with assurance at a given point in the river. The yield of the Krishna river was determined and accepted at $2060 \mathrm{tmc}$ at $75 \%$ dependability.

It is an acknowledged principle that priority should be given to factors and needs within the basin area of the river, although it is not unlawful to use the waters in areas outside the basin where there is no alternative source. Accordingly, the first Krishna Tribunal noted that various basin factors such as the drainage area, culturable area, population, scarcity area and drainage contribution have to be taken into consideration.

Karnataka commands the largest drainage area $(43.7 \%)$ of the Krishna basin. In Maharashtra, it spreads over $26.8 \%$, and in Andhra Pradesh it is $29.5 \%$. Karnataka has not used nor has made any claim for use outside the Krishna basin. Maharashtra and Andhra Pradesh indicated the extent of area outside the basin, where Krishna waters had been diverted, to use either for the generation of hydro power or for irrigation purposes. 
The First Krishna Tribunal evolved the test of 'committed utilization'. The party states mutually agreed for the protection of existing uses in the respective states, including projects under construction, which had been cleared by the central government by September 1960. It found that the state of Andhra Pradesh had been committed for projects utilizing $749.16 \mathrm{tmc}$ whereas Karnataka, in spite of its largest basin area, had been committed for projects using only 504.55 tmc, Maharashtra accounted for 439.65 tmc. The aggregate utilization under the protected uses of the party States, accounted to 1693.36 tmc. Deducting the said protected uses from the total available water of 2060 tmc (at 75\% dependability), the balance available for distribution amounted to $366.64 \mathrm{tmc}$.

The assessment of additional projects for the distribution of the balance quantity of dependable flow of $366.64 \mathrm{tmc}$ was undertaken by the tribunal from the projects and the uses claimed by the respective states. The principal contest related to the Nagarjun Sagar Project of Andhra Pradesh, the claim of the Almatti project in Karnataka and the claim of the Koyna Hydro Electrical Project in Maharashtra.

The First Krishna Tribunal ultimately divided the dependable flows of as 800 tmc for Andhra Pradesh, 565 tmc for Maharashtra and 700 tmc for Karnataka.

While the respective states moved ahead to utilize the waters of the Krishna, the tribunal considered it appropriate to limit the distribution to $2060 \mathrm{Tmc}$ of $75 \%$ dependability, for a period of 25 years. Since there was a legal impediment, the tribunal could not set up a machinery for the implementation of its decision. The tribunal directed that the respective shares be utilized en-bloc within the territories of each state. The tribunal did not direct project-wise allocations. Accordingly, each state drew up a master plan comprising projects for the use of allocated waters.

The great merit of the first Krishna Tribunal proceedings was to find solutions and to resolve the dispute. It innovated beyond the scope of the procedure. The parties experienced a productive blending of procedural imperatives and a practical, persuasive and coordinated approach involving them to appreciate the need to accept the tribunal's proposals for workable solution. Statesman 
like qualities was evident among the judges. One among them (Justice D.M. Bhandari, former Chief Justice of Rajasthan) would prefer to come down from the judge's seat on the dais and sit across surrounded by counsel, engineers and other technical experts representing states. The exchanges were fruitful, in recognizing areas of agreement on many important issues.

The First Krishna Tribunal, and its endeavours yielded a near perfect solution. Its decision even without machinery for implementation, has endured a period of over 35 years without major disputes among the states. There has been no court intervention at the instance of any party state.

The First Krishna Tribunal had drawn up Scheme B containing complete machinery for the implementation of its decision and for the utilization of surplus waters in due course based on the likely agreement of parties or law made by the Parliament. It did not, however, become possible for the states on their own, to agree nor was a law made for the purpose. The states limited the use of Krishna Waters to Scheme A concerning the dependable/dependability of $2060 \mathrm{tmc}$ in the aggregate. The tribunal however directed that it was open to the party states to seek a review after the year 2000.

Several years later, while considering the suit instituted by Karnataka seeking a direction to implement Scheme B in its entirety, by its order, the Supreme Court of India had occasion to consider the interplay of Article 131 and Article 262 It is as given below 33 :

The nature of the assertions made in the plaint and the relief sought for, it is difficult for us to hold that it constitutes a dispute within the meaning of Section 2(c) of the Act, and therefore, the jurisdiction of this Court gets barred under Article 262 read with Section 11 of the Act. In fact, the assertions made in the plaint and the relief sought for can be held to be a claim on the basis of an adjudicated dispute, the

${ }^{33}$ Devender Solanki v. D.D.A. and Anr., (2000) 9 S.C.C. 572. 
enforcement whereof is sought for by filing a suit under Article 131 of the Constitution. Such a suit cannot be held to be barred under Article 262 of the Constitution read with Section 11 of the Act.

The common composition of the tribunals for the Krishna as also for the Godavari Water Dispute, had the benefit of securing an agreement amongst the party States to the construction of the Polavaram project in the Godavari basin of the erstwhile state of Andhra Pradesh, for the diversion of $80 \mathrm{tmc}$ of available surplus flows from the Godavari to the water short basin of the Krishna to cater to the needs of the party states in the Krishna basin.

The Godavari tribunal was equally successful in persuading the party states in the Godavari basin to bring about agreements amongst them resolving the dispute. The result is commendable. The decision has stood the test of time without the need for a review and without court intervention for all this period of nearly 40 years.

The Second Krishna Tribunal was set up in April, 2004. Meanwhile the Act had been amended providing that any dispute settled by a tribunal before 2002 shall not be reopened. The Second Tribunal thus affirmed the decision of the First Krishna Tribunal without any modification. The Second Tribunal proceeded to distribute the surplus waters as ascertained by it at $65 \%$ dependability and at $50 \%$ dependability. The total availability of water for distribution increased from $2060 \mathrm{tmc}$ to $2293 \mathrm{tmc}$ at $65 \%$ dependability and 2626 Tmc at $50 \%$ dependability. It was found that Karnataka has the highest extent of drought area among the basin states. The tribunal made project-wise allocation. Karnataka gained by securing the Almatti Dam (to serve the drought areas of Raichur, Bagalkot and Bijapur districts) for a utilization of 302 tmc (Check whether rephrased part is correct or not). Its total allocation stood enhanced from 700 tmc to $907 \mathrm{tmc}$, while Maharashtra's allocation was 666 Tmc and that of Andhra Pradesh increased to 1001 Tmc. The tribunal also provided machinery for the implementation of its decision. Presently, however, the decision of the tribunal is pending appellate determination before the Supreme Court of India at the instance of Andhra Pradesh and Karnataka. 
Meanwhile consequent to the reorganisation of the State of Andhra Pradesh and its division into the successor states of Telangana and Andhra Pradesh, there has been an extension of the Second Krishna Tribunal's term by two years and a fresh reference of dispute on the bifurcation of the State. These proceedings are presently pending with the tribunal, requiring all the States including Karnataka and Maharashtra to participate. The tribunal is considering the scope of this new reference of dispute.

Reference may be made to the experience of tribunals set up so far under the Inter-State Water Disputes Act, 1956:

\begin{tabular}{|l|l|l|l|}
\hline Tribunal & \multicolumn{1}{|c|}{ Set-up on } & \multicolumn{1}{|c|}{$\begin{array}{c}\text { Award } \\
\text { pronounced } \\
\text { on }\end{array}$} & \multicolumn{1}{|c|}{ Present status } \\
\hline Krishna-I & 1969 & 1973 & -- \\
\hline Cauvery & June 1990 & Feb., 2007 & Pending in S.C. \\
\hline $\begin{array}{l}\text { Krishna- } \\
\text { II }\end{array}$ & April 2004 & Nov., 2010 & Pending in S.C. \\
\hline Godavari & $\begin{array}{l}1969 \\
\text { (effectively } \\
\text { from 1976 } \\
\text { to 1979) }\end{array}$ & 1979 & -- \\
\hline Narmada & 1969 & 1979 & $\begin{array}{l}\text { Extended up to 2000 The S.C. [(2000) } \\
\text { 10 SCC 664] has upheld the award } \\
\text { and directed the construction of the } \\
\text { dam as per the Award of the } \\
\text { Tribunal }\end{array}$ \\
\hline Ravi-Beas & 1986 & 1987 & $\begin{array}{l}\text { The Tribunal is examining the } \\
\text { matter. It is yet to submit its further } \\
\text { report to the Government on the } \\
\text { pleas submitted by the party States } \\
\text { as well as the Central Government } \\
\text { seeking explanation/ guidance on } \\
\text { its earlier report. In the meantime, a } \\
\text { Presidential reference on Punjab } \\
\text { Termination of Agreements Act, } \\
\text { 2004 is pending before the Supreme } \\
\text { Court. Hence, the further hearings of } \\
\text { the Tribunal and its final report are } \\
\text { now enjoined on the outcome of the } \\
\text { Supreme Court hearing of the } \\
\text { Presidential reference. }\end{array}$ \\
\hline
\end{tabular}




\begin{tabular}{|l|l|l|l|}
\hline Tribunal & Set-up on & \multicolumn{1}{|c|}{$\begin{array}{c}\text { Award } \\
\text { pronounced } \\
\text { on }\end{array}$} & Present status \\
\hline $\begin{array}{l}\text { Maha } \\
\text { dayi }\end{array}$ & Nov., 2010 & Pending & -- \\
\hline $\begin{array}{l}\text { Vamsha } \\
\text { dhara }\end{array}$ & Feb., 2010 & Pending & -- \\
\hline
\end{tabular}

\section{Conclusion}

The Inter-State Water Disputes Act, 1956 has based its provisions on the rights of states in waters of an Inter-State river and has provided for procedures for the adjudication of disputes. It may appear that such an approach has overlooked the nature of states in India. The states are not federal or autonomous or independent units as in the case of the United States of America. Many political scientists have variously described India as having the trappings of a unitary state. It is common knowledge that the Indian federation and states are all created under the Constitution. They are alterable by the Parliament at any point of time. The reorganisation of existing states and/or creation of more states such as Jharkhand, Chhattisgarh, Uttarakhand and Telangana are examples in this regard. Such changes have the potential to adversely affect the scope for implementation of the decision of a water disputes tribunal. The most recent example has been that of the decision rendered by the Second Krishna Tribunal.

The procedure for a trial as adopted by tribunals headed by judges has prolonged the proceedings. In fact almost all recent decisions are the subject of appeals pending before the Supreme Court. The court has become the terminus for all the disputes adjudicated by tribunals. The objective of the Inter-State Water Disputes Act, 1956 stands subordinated to the wider provision of Article 136 of the Constitution highlighting that in all matters of disputes, it is the Supreme Court, which should have the last say. After all, the aggrieved states would not be agreeable to the decisions of tribunals as it happens in the case of litigants.

There is also the aspect of political considerations in a large measure, governing the conduct of party states and the stand they 
take in the proceedings before tribunals. Reference may be made to the extensive efforts of the First Krishna Tribunal, in association with the counsel for the party states and their engineerrepresentatives, in evolving machinery for the implementation of its decision. Their efforts failed in the final stages, when the government of one of the party states conveyed its unwillingness while that of two other party States had signified their acceptance of agreed terms. Similar experience can be recalled in proceedings before the Supreme Court while hearing the President's Reference in In Re: Cauvery Water Disputes Tribunal. Political considerations have curtailed the liberty of counsels and engineers representing party States in water disputes referred to tribunals under the InterState Water Disputes Act, 1956.

Even the role of the central government in water disputes referred for adjudication to tribunals has not been constructive. The urge to resolve disputes in national interest, has not been evident.

The central government (of all political hues) appears to have assumed a formal role either during the mandatory negotiations prior to the reference of a water dispute to a tribunal or at later stages after the decision is rendered by a tribunal. The centre appears to maintain a distance from implementing its own National Water Policy (year to be mentioned) formulated periodically in association with the States and experts.

An example in this regard may be the direction of the central government initially clearing a drinking water project for the diversion of a small quantity of $7 \mathrm{tmc}$ in Mahadayi river basin and subsequently directing that the clearance accorded by it be kept in abeyance at the instance of one of the contesting party states for an indefinite period, resulting in years of inaction especially for a project of drinking water having priority under the National Water Policy.

The proceedings concerning the Cauvery dispute had been the subject of observation in an editorial in the Hindu paper, extracted below:

Taking the dispute back to the Supreme Court has defeated the very purpose for which the Tribunal was constituted. It is the guaranteed way of 
consuming time in years to the detriment of the interests of the farmers and people of the historically celebrated Cauvery basin. Both Tamil Nadu and Karnataka are paying a heavy economic price.

The Parliament enacted another Act known as the River Board Act 1956 by invoking Entry 56 List I of Schedule VII, to the Constitution, providing for the establishment of River Boards for the regulation and development of inter-state Rivers. This board contemplated the exercise of control by the central government and invoked procedures of arbitration in the event of disputes between states. This enactment could have brought solutions and promoted water projects as national projects, but this enactment has remained unimplemented. It maybe attributed to the reason that the centre has considered it advisable to avoid disputes with States for legal or political reasons.

What is of significance is the nature of uses to which water is put, including the promotion of agriculture, power generation and for other purposes such as domestic and industrial use. They include drinking water which is of utmost priority. In other words, such requirements are common to all parts of the country whether belonging to one state or the other. Looked at from that point of view, the resolution of a water dispute has national significance in promoting progress as in the case of educational institutions or industrial units. Such a water dispute is required to be resolved expeditiously to promote national and public interests. It should not be the subject of protracted and/or appellate proceedings. In fact there can be different views, that the central government may appropriately play an effective role in securing solution to such disputes in national interest.

It may well be that the suggestions made by the eminent jurist Mr. Fali S. Nariman would be of guidance. ${ }^{34}$ According to him, the rights and procedures concerning water disputes and their adjudication would be better served by the provisions of the Constitution under Article 131 (by means of an original suit) in place of the Inter-State Water Disputes Act, 1956. He has

34 FALi S. NARIMAN, BEFORE MEMORY FADES: AN AutOBIOGRAPHY 294-295 (New Delhi: Hay House India, 2010). 
commencing an investigative proceeding in place of recording evidence and cross-examination. He has commended the precedent of the first Krishna Water Disputes Tribunal especially in respect of the approach adopted by the members of that Tribunal directly discussing the technical aspects involved with engineers and the respective parties without seeking any assistance from legal representatives of the party States. It was an effort made by the tribunal to find a workable solution to a complex dispute and not to be victimized by laws and their interpretation. The tribunal succeeded in securing agreements of party States. As the first tribunal set up under the Inter- State Water Disputes Act, 1956 its labours provides a model even in present times. As already stated, it is the only tribunal whose decision has been implemented for over 40 years even without an implementation body, without being subjected to court interference. The recommendations of Mr. Nariman deserve appreciation. It is as provided below:-

a. The mindset of tribunal members, lawyers, engineers and participants must be so conditioned so as to gather all necessary information with as little formality as possible, so that the tribunal reaches an informed decision on the points required to be decided.

b. The chairman of the tribunal along with the members must, on an almost continuous basis, caucus (discuss) with the engineers and technical experts on each side, preferably keeping lawyers in the background so that the tribunal acquaints itself with all the finer technical points at issue in the case. Of course this would be after presentations are made by the technical experts on each side.

c. Adversarial form of recording of evidence (as in a court of law) must be avoided viz. the rigmarole of examination-in-chief (or its poor substitute-an affidavit in support) of every witness, the cross-examination of that witness and his (her) re-examination, as in a proceeding in a court of law is definitely not the 
recommended mode of proceeding under the 1956 Act.

d. After the presentations are made, the lawyers could usefully sum up and give an analysis of the documentation on record and point to relevant conclusions.

e. This change in the modus operandi of the functioning of interstate water dispute tribunals can only be achieved by a change in the mindset of members of the tribunal - who must not sit like umpires in a cricket match. Rather, they should emulate the referee in a football match running with the 'players', all along participating in 'the game, though in a supervisory capacity.'

The Supreme Court of India has over the years pronounced on the law concerning water disputes. They may usefully be referred to and may be a useful guide in the context of Indian experience 35

It is now a matter for the States and the Centre in co-operation, to consider certain measures to achieve progress, while appreciating that India should be a fore-runner among the developing countries. Engineers and technocrats in association with law makers and academicians from educational centres and universities may combine in national interest.

35 Tamil Nadu Cauvery Sangam v. Union of India and Others (1990) 3 S.C.C. 440; State of Tamil Nadu v. State of Karnataka and Ors.- 1991 Supp. (1) S.C.C. 240; In the matter of : Cauvery Water Disputes Tribunal1993 Supp(1) S.C.C. 96, State of Karnataka v. State of Andhra Pradesh \& Ors.(2000) 9 S.C.C. 572 and Mullaperiyar dispute: (2014) 12 S.C.C. 696. 